\title{
Korelasi antara Trombositopenia Imunoglobulin M dan Imunoglobulin G pada Anak yang Menderita Dengue Haemorrhagic Fever
}

\author{
Hariyanto $^{1}$, Evy Diah Woelansari ${ }^{2}$, Suliati $^{2}$ \\ ${ }^{1}$ Prodi D3 Analis Kesehatan STIKes Hutama Abdi Husada Tulungagung \\ ${ }^{2}$ Dosen Politeknik Kesehatan Kemenkes Surabaya \\ Email : hariyanto696@gmail.com
}

Received 7 April 2018; Accepted 8 May 2018; Published 15 May 2018

\begin{abstract}
ABSTRAK
DHF merupakan demam berdarah dengue yang disebabkan oleh virus dengue yang ditularkan oleh nyamuk Aedes aegypti. Demam Berdarah Dengue dengan gejala umum demam, nyeri sendi, lekopenia dengan salah satunya trombositopeni. Demam akibat infeksi virus menyebabkan respon imun yaitu IgM dan IgG yang berasal dari limfosit B. Penelitian ini bertujuan untuk membuktikan adanya hubungan antara trombositopeni dengan imunoglobulin $M$ dan imunoglobulin G pada anak yang menderita DHF. Penelitian ini bersifat deskriptif analitik yang dilakukan antara bulan Januari sampai Juni 2013 di laboratorim RSU Dr. Iskak Tulungagung. Dari pemeriksaan terhadap 60 kasus yang mengalami penurunan trombosit $<100.000 / \mathrm{mm}^{3}$ atau trombositopeni terdapat hasil $\mathrm{IgG}$ yang reaktif $23(38,3 \%) \mathrm{IgG}$ yang nonreaktif $14(23,3 \%)$ IgM yang reaktif $26(43,3 \%)$ IgM yang non reaktif $11(18,3 \%)$ yang negatif IgG dan IgMnya walaupun trombositopeni sebanyak 23 $(28,3 \%)$ dari hasil penelitian lanjutan dengan statistik dilakukan uji non parametrik corelation didapatkan $p=0,000$ pada IgG dan $p=0,000$ pada IgM artinya $p<\alpha$. Artinya ada hubungan antara trombositopenia dengan imunoglobulin $M$ dan imunoglobulin $G$ pada anak yang menderita dengue haemorhagic fever. Korelasi yang terjadi antara yang terjadi adalah korelasi yang kuat dan searah artinya apabila trombosit naik maka IgM dan IgG naik atau sebaliknya. Untuk hubungan IgG dan IgM didapat nilai $r=0,590$ pada $\alpha=0,01$. Artinya hubungan $\operatorname{IgG}$ dan IgM mempunyai kuat hubungan sedang dan searah.
\end{abstract}

Kata Kunci : DHF, IgG, IgM, trombositopeni.

Copyright $\odot 2018$ STIKes Surya Mitra Husada

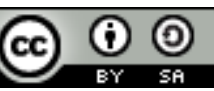

This is an open-acces article distributed under the terms of the Creative Commons Attribution-ShareAlike 4.0 International License. 


\section{PENDAHULUAN}

Pada musim hujan banyak penyakit bermunculan salah satu yang patut kita waspadai dan paling banyak mewabah adalah Demam Berdarah Dengue (DBD) atau Dengue Hemorrahagic Fever (DHF) (Woman, 1991).

Penyakit demam berdarah Dengue atau yang disingkat DBD adalah suatu penyakit yang disebabkan oleh virus Dengue yang dibawa oleh nyamuk Aedes aegypti betina lewat air liur gigitan saat menghisap darah manusia. DBD ini termasuk penyakit akut yang disebabkan oleh salah satu virus dari kelompok flafivirus yang memiliki 4 serotipe berbeda yaitu : Den 1, Den 2, Den 3 dan Den 4. Virus Dengue ini dibawa melalui nyamuk aedes aegypti dan menulari manusia melalui gigitannya dan akibat infeksi virus tersebut menimbulkan bermacam-macam gejala seperti Asymtomatis, Mild Undifferentiated Febrile limes Dengue Fever (Demam Dengue) Dengue Shock Syndrome (DDS) Dengue dan Haemorhagic Fever (DHF-DBD) (Woman, 1991).

Penularannya melalui gigitan nyamuk Aedes aegypti yang sudah terkontaminasi virus Dengue. Jika nyamuk tersebut menghisap darah penderita DBD maka nyamuk menjadi berbahaya karena bisa menularkan virus Dengue yang mematikan. Untuk itu perlu pengendalian nyamuk jenis Aedes aegypti agar virus Dengue tidak menular dari orang yang satu ke orang yang lain.

Dengue Hemorrahagic Fever (DHF) merupakan re-emerging disease dan endemis di seluruh negara beriklim tropis di dunia. Penyakit ini juga bisa ditemukan di kawasan subtropis. Meskipun begitu, Asia Tenggara merupakan daerah dengan angka kejadian tertinggi yang terutama menyerang anak-anak. Berdasarkan data WHO, 250.000 hingga 500.000 kasus DBD terjadi setiap tahunnya dengan angka kematian mencapai 22.000 jiwa. Di Indonesia penyakit ini menempati urutan ke-19 penyebab kematian semua umur. Kasus yang terjadi di Kabupaten Tulungagung 1.410 kasus DB pada tahun 2010 dan terjadi penurunan di tahun 2011 sebanyak 67 kasus (Woman, 1991).

DBD dapat didefinisikan sebagai suatu sindrom yang timbui akibat infeksi virus Dengue dengan gejala utama demam, nyeri otot dan/atau nyeri sendi yang disertai leukopenia, limfadenopati, trombositopenia, dan diatesis hemoragik, Menurut kriteria WHO 1999, diagnosisnya ditegakkan berdasarkan pemeriksaan klinis yang menunjukkan adanya demam antara 2-7 hari, tanda-tanda perdarahan, hepatomegali, dan syok, pemeriksaan laboratorium yang memperlihatkan trombositopeni dan hemokonsentrasi (Notoatmojo, 2003).

Demam tidak hanya merupakan respon terhadap suatu infeksi tetapi juga sebagai strategi pertahanan tubuh terhadap penyakit. Pada kondisi ini produksi antibodi dan proliferasi serta aktivasi sel limfosit-T meningkat sampai dengan 20 kali dibandingkan pada temperatur normal (Notoatmojo, 2003).

Pada proses infeksi Dengue salah satu respon imun yang berperan adalah respon imun seluler yaitu limfosit T. Sel limfosit T, baik 1-helper (CD4+) dan T-sitotoksik (CD8+), akan teraktivasi akibat stimulus sitokin seperti IFN atau karena adanya infeksi makrofag oleh virus. Sel T CD4+ mengaktivasi sel limfosit B untuk kemudian membentuk immunoglobulin (terutama $\operatorname{IgM}$ dan $\operatorname{IgG}$ ) yang berasal dari sel-sel plasma limfosit B. Pembentukan immunoglobulin (khususnya IgM) di awal saat Dengue masuk ke dalam tubuh berperan untuk mengeliminasi virus. Jika kadar IgM rendah, infeksi akan berjalan lebih berat karena proses eliminasi virus tidak memadai.

Banyaknya penderita demam berdarah pada anak di Kabupaten Tulungagung menjadikan peneliti berkeinginan membuktikan adanya hubungan antara penurunan jumlah thrombosit dengan IgM dan IgG pada pada anak yang menderita demam berdarah Dengue. Hasil penelitian yang diperoleh harapannya bermanfaat untuk membantu diagnosis dan menambah informasi mengenai imunopatogenesis demam berdarah Dengue. Tujuan penelitian ini adalah untuk mengetahui apakah terdapat hubungan antara Trombositopenia dengan Imunoglobulin M dan Imunoglobulin G pada anak yang menderita Dengue Haemorrhagic Fever. 


\section{BAHAN DAN METODE}

Penelitian ini bersifat deskriptif analitik yang dilakukan antara bulan Januari sampai Juni 2013 di laboratorim RSU Dr. Iskak Tulungagung. Waktu penelitian dilakukan pada bulan Januari sampai dengan Juni 2013. Populasi dalam penelitian ini diambil dari pasien IGD yang berumur antara 3 sampai 12 tahun yang menderita panas 2 sampai 7 hari, yang diminta oleh Dokter untuk periksa IgG, IgM Dengue. Sampel penelitian yang diambil sebanyak 37 sampel yang diperiksa trombosit, IgG, IgM di Laboratorium RSUD Dr. Iskak Tulungagung. Sampel yang diperiksa sebanyak 35 sampel. Variabel dalam penelitian ini adalah Variabel bebas yaitu jumlah trombosit dan variabel terikat yaitu $\operatorname{IgG}$ dan $\operatorname{IgM}$ dengue.

\section{HASIL PENELITIAN}

Table 1. Hasil pemeriksaan $\operatorname{IgG} / \operatorname{IgM}$ dan trombosit di Laboratorium RSUD Dr. Iskak Tulungagung di Bulan Maret 2013.

\begin{tabular}{|c|c|c|c|c|c|c|}
\hline \multirow{2}{*}{ No } & \multirow{2}{*}{ Kode sampel } & \multirow{2}{*}{ Usia } & \multirow{2}{*}{$\mathbf{L} / \mathbf{P}$} & \multicolumn{2}{|c|}{ Pem. Dengue } & \multirow{2}{*}{ Jumlah trombosit } \\
\hline & & & & IgG & IgM & \\
\hline 1 & RD & 4 & $\mathrm{~L}$ & $\mathrm{R}$ & $\mathrm{R}$ & 64.000 \\
\hline 2 & DEN & 6 & $\mathrm{~L}$ & $\mathrm{R}$ & $\mathrm{R}$ & 81.000 \\
\hline 3 & SEN & 8 & $\mathrm{P}$ & $\mathrm{R}$ & $\mathrm{R}$ & 62.000 \\
\hline 4 & EM YU & 7 & $\mathrm{P}$ & $\mathrm{R}$ & $\mathrm{R}$ & 72.000 \\
\hline 5 & FA & 6 & $\mathrm{P}$ & NR & NR & 138.000 \\
\hline 6 & JA & 10 & $\mathrm{~L}$ & $\mathrm{R}$ & NR & 101.000 \\
\hline 7 & $\mathrm{CAN}$ & 9 & $\mathrm{~L}$ & NR & NR & 128.000 \\
\hline 8 & EL SI & 8 & $\mathrm{P}$ & $\mathrm{R}$ & $\mathrm{R}$ & 91.000 \\
\hline 9 & WIL & 6 & $\mathrm{P}$ & $\mathrm{R}$ & $\mathrm{R}$ & 88.000 \\
\hline 10 & $\mathrm{NOV}$ & 5 & $\mathrm{P}$ & NR & NR & 140.000 \\
\hline 11 & YUS & 3 & $\mathrm{~L}$ & NR & NR & 147.000 \\
\hline 12 & KAS & 11 & $\mathrm{~L}$ & $\mathrm{R}$ & $\mathrm{R}$ & 88.000 \\
\hline 13 & $\mathrm{BI}$ & 9 & $\mathrm{P}$ & $\mathrm{R}$ & $\mathrm{R}$ & 94.000 \\
\hline 14 & HIN & 8 & $\mathrm{~L}$ & $\mathrm{R}$ & $\mathrm{R}$ & 96.000 \\
\hline 15 & IS & 4 & $\mathrm{P}$ & NR & NR & 142.000 \\
\hline 16 & YUS & 6 & $\mathrm{P}$ & $\mathrm{R}$ & $\mathrm{R}$ & 54.000 \\
\hline 17 & ETRI & 7 & $\mathrm{P}$ & $\mathrm{R}$ & $\mathrm{R}$ & 94.000 \\
\hline 18 & RAY & 11 & $\mathrm{~L}$ & $\mathrm{R}$ & $\mathrm{R}$ & 81.000 \\
\hline 19 & YUY & 3 & $\mathrm{P}$ & NR & NR & 144.000 \\
\hline 20 & DAV & 10 & $\mathrm{~L}$ & $\mathrm{R}$ & $\mathrm{R}$ & 89.000 \\
\hline 21 & BIM & 9 & $\mathrm{~L}$ & $\mathrm{R}$ & $\mathrm{R}$ & 36.000 \\
\hline 22 & MIL & 3 & $\mathrm{~L}$ & $\mathrm{R}$ & $\mathrm{R}$ & 88.000 \\
\hline 23 & ISRO & 5 & $\mathrm{P}$ & NR & $\mathrm{R}$ & 132.000 \\
\hline 24 & IQ & 12 & $\mathrm{~L}$ & $\mathrm{R}$ & $\mathrm{R}$ & 98.000 \\
\hline 25 & MAR & 10 & $\mathrm{~L}$ & NR & NR & 148.000 \\
\hline 26 & SUJ & 9 & $\mathrm{~L}$ & $\mathrm{R}$ & $\mathrm{R}$ & 83.000 \\
\hline 27 & AND & 10 & $\mathrm{P}$ & NR & NR & 180.000 \\
\hline 28 & $\mathrm{AG}$ & 8 & $\mathrm{~L}$ & $\mathrm{R}$ & $\mathrm{R}$ & 94.000 \\
\hline 29 & SA & 6 & $\mathrm{P}$ & $\mathrm{R}$ & $\mathrm{R}$ & 84.000 \\
\hline 30 & KRIS & 7 & $\mathrm{P}$ & $\mathrm{R}$ & $\mathrm{R}$ & 71.000 \\
\hline 31 & IST & 10 & $\mathrm{P}$ & $\mathrm{R}$ & NR & 104.000 \\
\hline 32 & OKT & 9 & $\mathrm{~L}$ & NR & NR & 146.000 \\
\hline 33 & SUN & 8 & $\mathrm{~L}$ & $\mathrm{R}$ & NR & 102.000 \\
\hline 34 & AR & 3 & $\mathrm{P}$ & $\mathrm{R}$ & $\mathrm{R}$ & 77.000 \\
\hline 35 & $\mathrm{ROH}$ & 5 & $\mathrm{~L}$ & NR & $\mathrm{R}$ & 104.000 \\
\hline 36 & FEN & 4 & $\mathrm{P}$ & $\mathrm{R}$ & NR & 202.000 \\
\hline 37 & SLA & 8 & $\mathrm{~L}$ & $\mathrm{R}$ & NR & 104.000 \\
\hline
\end{tabular}


Keterangan :

R : Reaktif

NR : Non Reaktif

Dari hasil tabel.1 menunjukkan bahwa hasil pemeriksaan dari 37 kasus IgG yang reaktif 26 pasien, $\operatorname{IgG}$ yang non reaktif 11 pasien sedangkan IgM yang reaktif 23 pasien yang non reaktif 14 pasien.

Hasil penelitian dari 37 kasus yang diperiksa $\operatorname{IgG} / \operatorname{IgM}$ di laboratorium RS Dr. Iskak Tulungagung terdapat IgG reaktif 26 pasien, terdiri dari yang laki-laki 14 pasien yang perempuan 12 pasien. IgG yang non reaktif 11 pasien, terdiri dari perempuan 5 pasien, laki - laki 6 pasien sedangkan pada pemeriksaan IgM yang reaktif 23 pasien terdiri dari lakilaki 12 pasien yang perempuan 11 pasien dan IgM yang non reaktif 14 pasien terdiri dari 7 pasien laki-laki dan perempuan 7 pasien.Karakteristik Subyek.

\section{HASIL UJI STATISTIK}

\section{Hasil uji korelasi didapat nilai sebagai berikut :}

Usia pasien dan jenis kelamin ada hubungan dengan kuat hubungan $r=-0,367$ pada $\alpha$ $=0,05$ artinya hubungan lemah dengan berlawanan arah.

Sedangkan untuk IgM dengan jumlah Trombosit kuat hubungan yang didapat $r=$ 0,728 dan IgG dengan jumlah trombosit didapat nilai $r=0,799$ pada $\alpha=0,01$ artinya kuat hubungan yang diperoleh kuat dan searah, artinya apabila trombosit naik maka IgM dan $\operatorname{IgG}$ naik atau sebaliknya.

Untuk kuat hubungan $\operatorname{IgG}$ dan $\operatorname{IgM}$ didapat nilai $\mathrm{r}=0,590$ pada $\alpha=0,01$. Artinya kuat hubungan IgG dan IgM mempunyai kuat hubungan sedang dan searah artinya apabila $\operatorname{IgG}$ naik IgM naik atau sebaliknya.

\section{PEMBAHASAN}

Dengue Haemorrogic fever masalah yang besar bagi kesehatan masyarakat. Salah satunya penyakit yang membahayakan pada anak-anak dan angka kejadiannya cenderung mengalami peningkatan terutama pada sekitar bulan Januari atau dimusim penghujan. Dari hasil penelitian yang dilakukan terhadap pasien DHF yang diperiksa di Laboratorium RSU Dr. Iskak Tulungagung bahwa sebagian suspect DHF yang diperiksa dari 37 suspect IgM yang reaktif $26=70,3 \%$, IgM yang non reaktif $11=29,7 \%$. Dan IgG yang reaktif $23=62 \%$, IgG yang non reaktif $14=37,8 \%$ dari 37 suspect yang mengalami penurunan trombositnya dan setelah diperiksa IgG dan IgM nya hasilnya reaktif. Dari hasil pemeriksaan pasien dengan gejala $2-7$ hari dan mengalami trombosit yang menurun 100.000 menunjukan hasil laboratorium dalam Table 5.1 Hasil pemeriksaan IgG dan IgM.

Hasil penelitian dari 37 kasus yang diperiksa $\operatorname{IgG} / \operatorname{IgM}$ di laboratorium RS Dr. Iskak Tulungagung terdapat IgG reaktif 26 pasien (70,3\%) dari yang laki-laki 14 pasien $37,8 \%$, yang perempuan 12 pasien $32,4 \%$.

IgG yang non reaktif 11 pasien $29,7 \%$, terdiri dari perempuan 5 pasien $13,5 \%$, lakilaki 6 pasien 16,2\%, sedangkan pada pemeriksaan IgM yang reaktif 23 pasien 62,2\%, terdiri dari laki-laki 12 pasien $32,4 \%$, yang perempuan 11 pasien $29,7 \%$ dan IgM yang non reaktif 14 pasien 37,8\% terdiri dari 7 pasien 18,9\% laki-laki dan perempuan 7 pasien $18,9 \%$. 


\section{KESIMPULAN DAN SARAN}

\section{Kesimpulan}

1. Menganalisis Imunoglobulin M pada anak yang menderita Dengue Haemorrhagic Fever imunoglobulin $\mathrm{M}$ akan meningkat ada infeksi virus DHF hepatitis dan sebagainya pada anak yang mendrita DHF imunoglobulin ini muncul setelah demam hari kedua dan meningkat tetapi cepat hilang.

2. Menganalisis Imunoglobulin G pada anak yang menderita Dengue Haemorrhagic Fever. Imunoglobulin $\mathrm{G}$ ini muncul setelah infeksi hari ke 4 dan meningkat sampai hari ke 7 menggantikan imunoglobulin $\mathrm{M}$ yang menghilang dan pada infeksi ini respon imun IgG akan bertahan lebih lama dalam tubuh.

3. Menganalisis jumlah trombosit pada pasien Dengue Haemorrhagic Fever. Jumlah trombosit pada infeksi DHF ini mengalami penurunan hingga kurang dari 100.000 dikarenakan terjadinya pendarahan dalam seluler pada peristiwa pteikie.

\section{Saran}

1. Dianjurkan melakukan pola hidup bersih dan sehat atau PHBS.

2. Kegiatan untuk mencegah terjadinya DHF antaranya : mengubur kaleng bekas, menguras bak mandi, melakukan fogging bilamana terjadi wabah DHF.

3. Setelah menderita panas lebih dari 2 hari segera bawa ke rumah sakit untuk antisipasi penularan DHF.

4. Jaga kebersihan lingkungan, untuk anak disarankan menggunakan lotion anti nyamuk saat bepergian.

\section{DAFTAR PUSTAKA}

Aryati. (2009). Mendeteksi Demam Berdarah dengan Cepat. Vol 3 (6).

Narsi, N. (1997). Pengantar Epidemiologi Penyakit Menular. Jakarta : Rineka Cipta.

Notoatmojo. (2002). Metodologi Penelitian Kesehatan. Rineka Cipta : Jakarta.

Nursalam. (2008). Konsep dan Penerapan Methodologi Penelitian dalam Keperawatan, Salemba : Jakarta.

Setiadi. (2007). Buku Konsep dan Penelitian Riset Keperawatan. Jakarta : Graha Ilmu.

Soegijanto, S. (2004). Demam Berdarah Dengue. Airlangga University Press Surabaya.

Sri, R.H., Hadinegoro, Satari, H.I. (1999). Demam Berdarah Dengue. Jakarta : FKUI.

Suharjono. (2001). Ilmu Penyakit Dalam. Jilid II. Edisi Ketiga. Balai Penerbit FKUI. Jakarta.

Underwood. (2000). Patologi Umum dan Sistemik. Edisi 2. Penerbit Buku Kedokteran. Jakarta.

Woman, M. (1993). The Yellow Fever Mosquito, Aedes Aegypti Wing Beats Vol 5 (4)www.blogdokter.net/2008/06/27/demam-berdarah-dengue. 